\title{
Energetic-protein supplementation in the last 60 days of gestation improves performance of beef cows grazing tropical pastures
}

Aline Gomes da Silva ${ }^{1,2^{*}}$ D, Mário Fonseca Paulino ${ }^{1}$, Edenio Detmann ${ }^{1}$, Henrique Jorge Fernandes ${ }^{3}$, Lincoln da Silva Amorim ${ }^{1,4}$, Román Enrique Maza Ortega', Victor Valério de Carvalho, Josilaine Aparecida da Costa Lima ${ }^{1}$, Felipe Henrique de Moura ${ }^{1}$, Mariana Benevides Monteiro ${ }^{5}$ and Jéssika Almeida Bitencourt ${ }^{1}$

\begin{abstract}
Background: Nutrition is one of the most important factors that affect animal performance, and it therefore also impacts on financial results in beef systems. In this way, finding the best strategy for feeding supplements is of paramount importance. Aiming to evaluate the effect of supplement feeding strategies for beef cows in the last third of gestation, two experiments were conducted. In Experiment 1, 35 pregnant Nellore cows were assigned to a completely randomized design with four treatments: control, which received no supplement; supplementation for the last $30 \mathrm{~d}$ of gestation (30-d; $3.0 \mathrm{~kg} / \mathrm{d}$ ); supplementation for the last $60 \mathrm{~d}$ of gestation (60-d; $1.5 \mathrm{~kg} / \mathrm{d})$; or supplementation for the last $90 \mathrm{~d}$ of gestation $(90-\mathrm{d} ; 1.0 \mathrm{~kg} / \mathrm{d})$. All supplemented treatments received the same total amount of supplement throughout the experiment: $90 \mathrm{~kg}$ (20\% of crude protein). A second experiment (Experiment 2) was delineated to evaluate the effects of the amounts offered in Experiment 1 on intake and metabolism. Four multiparous pregnant Nellore cows were assigned to a $4 \times 4$ Latin square design, with periods of $15 \mathrm{~d}$ each.

Results: There was a linear effect of the number of days of supplementation on calving body weight $(B W ; P<0.05)$ and a quadratic effect on BW change from parturition to d 31 post-calving $(P<0.05)$, with cows on the 60-d strategy losing less BW post-calving. No difference was found in offspring birth BW $(P>0.10)$. A significant linear effect on interval from parturition to conception $(P<0.05)$ was observed, with the highest calving to conception interval being observed in the 90-d strategy. The level of supplementation did not affect forage intake or neutral detergent fiber digestibility $(P>0.10)$. Nitrogen excreted through urine tended to increase linearly with the level of supplementation $(P<0.10)$.
\end{abstract}

Conclusion: Providing $1.5 \mathrm{~kg}$ of supplement during the last $60 \mathrm{~d}$ of gestation improves cow performance after calving, reducing the magnitude of BW lost, and reduces the number of days from calving to re-conception in the following breeding season compared to the usually recommended period of supplementation of $90 \mathrm{~d}$ pre-partum.

Keywords: Flushing, Nutrition, Parturition, Reproduction

\footnotetext{
* Correspondence: alinegomesdasilva@rocketmail.com; aline.g.silva@ufms.br

${ }^{1}$ Universidade Federal de Viçosa, Viçosa, Minas Gerais 36570-000, Brazil

${ }^{2}$ Present Address: Universidade Federal de Mato Grosso do Sul, Campo

Grande, Mato Grosso do Sul 79074-460, Brazil

Full list of author information is available at the end of the article
} 


\section{Background}

It is estimated that $50 \%$ of the cows in extensive beef systems do not receive adequate nutritional management, and this is a main reason for low fertility rates in tropical herds [1].

Among the factors affecting the reproductive performance of beef cattle, nutrition has perhaps the highest impact [2]. Supplementation to grazing animals is a practice that can be adopted under tropical conditions to increase animal performance. Because the last third of gestation usually coincides with the dry season and, consequently, with low quantity and quality of forage, producers in tropical conditions, as in Brazil, are usually oriented to supplement pregnant cows for the last $90 \mathrm{~d}$ of gestation.

The objective with this experiment was to study whether this period of supplementation could be reduced to avoid extra labor and, consequently, reduce feeding costs. Therefore, we conducted a study to evaluate the effects of different supplementation strategies for pregnant beef cows in the last third of gestation, receiving supplementation for 90,60 or $30 \mathrm{~d}$ pre-partum.

\section{Methods}

The two experiments were conducted at the Department of Animal Science - Universidade Federal de Viçosa, Brazil, from July to December 2012. All animal care and handling procedures were ethically standardized and approved by the Animal Care and Use Committee of the Universidade Federal de Viçosa, Brazil.

\section{Experiment 1 - Performance}

Thirty-five multiparous, at an average age of five years old, single pregnant Nellore cows with $491.88 \pm 55 \mathrm{~kg}$ of body weight (BW), a body condition score (BCS) of $4.7 \pm 0.58$ and $200 \pm 15 \mathrm{~d}$ of gestation were used. Cows were housed in an experimental area of Brachiaria decumbens divided into four paddocks of 5.0 ha each, and had unlimited access to water, feeders and mineral salt $(8.7 \%$ calcium, $9.0 \%$ phosphorous, $18.7 \%$ sodium, $9.0 \%$ sulfur, $2,400 \mathrm{mg} / \mathrm{kg}$ of zinc, $800 \mathrm{mg} / \mathrm{kg}$ of copper, $1,600 \mathrm{mg} / \mathrm{kg}$ of manganese, $40.0 \mathrm{mg} / \mathrm{kg}$ of iodine, $8.00 \mathrm{mg} / \mathrm{kg}$ of cobalt and $8.16 \mathrm{mg} / \mathrm{kg}$ of selenium). To avoid any effects of paddock on the responses, treatments were rotated among paddocks every $10 \mathrm{~d}$.

Four strategies were evaluated: $30-\mathrm{d}$ - cows received $3.0 \mathrm{~kg} / \mathrm{d}$ of supplement beginning $30 \mathrm{~d}$ prior to calving; $60-\mathrm{d}$ - cows received $1.5 \mathrm{~kg} / \mathrm{d}$ of supplement beginning $60 \mathrm{~d}$ prior to calving; $90-\mathrm{d}$ - cows received $1.0 \mathrm{~kg} / \mathrm{d}$ of supplement beginning $90 \mathrm{~d}$ prior to calving; and control - no concentrate supplement was fed. All supplemented treatments received the same total amount of supplement throughout the experiment, $90 \mathrm{~kg} / \mathrm{d}$ per head.
Animals were assigned to a completely randomized design with four treatments. There were nine cows each in the control group, 60- $\mathrm{d}$ and 90-d supplemented groups, and eight cows in the 30-d supplemented group. Supplement was fed in a collective feeder, which is experimental handling closer to what is normally observed in beef production systems due to cattle gregarious behavior. As the evaluations in Experiment 1 were focused on individual performance, and these measurements were collected individually, the animal was considered the experimental unit, as recommended by Detmann et al. [3].

Supplement was composed of corn, sorghum and soybean meal, and formulated to contain approximately $20 \%$ crude protein (CP; Table 1). The level of supplementation adopted for the 90-d treatment corresponds to the daily supply of $1 \mathrm{~kg}$ of supplement to approximately $23 \%$ of the requirements of $\mathrm{CP}$ and $17 \%$ of the daily energy requirements of a pregnant Nellore cow, with average BW of $465 \mathrm{~kg}$ and expected calf birth BW of $32 \mathrm{~kg}$ [4]. The other supplemented treatments were based on the supply of the same total amount of energy and $\mathrm{CP}$, but offered in a reduced period of feeding.

Cow BW was recorded at the beginning of the experiment, approximately $90 \mathrm{~d}$ prior to the day of calving, at the week before the expected date of parturition (calving $\mathrm{BW})$, and $31 \mathrm{~d}$ after parturition. Cow BCS was recorded at the beginning of experiment, prior to calving and in the first day of the breeding season on a scale ranging from 1 to 9 , as recommended by NRC [5] by two experienced technicians. Calf BW was also recorded at birth. Shrunk BW (SBW) was calculated using adjustments proposed by Gionbelli et al. [6] for Nellore cows as follows:

$$
\mathrm{SBW}=0.8084 \times \mathrm{BW}^{1.0303}
$$

After calving, cows were managed as a single herd until after pregnancy was diagnosed. During this period,

\begin{tabular}{ll} 
Table $\mathbf{1}$ Ingredients and chemical composition of supplements \\
\hline Item $^{\text {a }}$ & Supplement \\
\hline Ingredients, \% as-fed basis & 33 \\
Corn & 33 \\
Sorghum & 34 \\
$\quad$ Soybean meal & \\
Chemical composition, g/kg & 971 \\
OM & 208 \\
CP & 164 \\
apNDF & \\
\hline
\end{tabular}

${ }^{a} \mathrm{OM}$ - organic matter; CP - crude protein; apNDF - neutral detergent fiber corrected for ash and protein residue 
all cows grazed the same pasture and received mineral supplement ad libitum.

Twenty-one and $31 \mathrm{~d}$ after calving, blood samples were taken from the jugular vein using vacuum tubes with clot accelerator and gel for serum separation (BD Vacuntainer ${ }^{\bullet}$ SST II Plus, São Paulo, Brazil). Immediately after collection, the samples were centrifuged at 3,600 $\times \mathrm{g}$ for $20 \mathrm{~min}$. Then, the serum was frozen at $-20{ }^{\circ} \mathrm{C}$ and subsequently analyzed for progesterone by the chemiluminescent method using Access Progesterone Reagent Kit (Ref. Number 33550, Beckman Coulter ${ }^{\circ}$, Brea, USA) in the Access 2 Immunoassay System (Beckman Coulter Inc., Brea, USA).

Pasture chemical composition (Table 2) was assessed by hand-plucked samples every two weeks. In the middle of every experimental month, a second pasture sample was also collected to estimate forage potentially digestible dry matter (pdDM) as proposed by Detmann et al. [5]. Four subsamples were randomly collected in each plot by cutting it close to the ground using a metal square $(0.5 \mathrm{~m} \times 0.5 \mathrm{~m})$. Samples were weighed and oven dried at $60{ }^{\circ} \mathrm{C}$ for $72 \mathrm{~h}$. After that, samples were mill grinded to pass through a 2-mm screen for indigestible neutral detergent fiber (iNDF) analysis [7]. A sub portion of $20 \mathrm{~g}$ of each sample was grinded to pass through a 1-mm screen for analyses of dry matter $(\mathrm{DM})$, ash, crude protein $(\mathrm{CP})$ and neutral detergent fiber (NDF).

Samples of forage were analyzed following procedures described by Detmann et al. [7] for DM (index INCTCA G-003/1), CP (index INCT-CA N-001/1), ash (index INCT-CA M-001/1), NDF corrected for contaminant ash and protein (apNDF; index INCT-CA F-002/1, INCT-CA M-002/1, and INCT-CA N-004/1). The iNDF was evaluated using F57 filter bags $\left(\right.$ Ankom $\left.^{\circ}\right)$ by a $288-\mathrm{h}$ in situ incubation procedure [7].

Table 2 Potentially digestible forage mass and chemical composition of forage in Experiment 1

\begin{tabular}{llll}
\hline Item $^{\mathrm{a}, \mathrm{b}}$ & \multicolumn{3}{l}{ Experimental month } \\
\cline { 2 - 4 } & 1 & 2 & 3 \\
\hline $\mathrm{pdDM}, \mathrm{kg} / \mathrm{hm}^{2}$ & 4820 & 4050 & 3410 \\
$\mathrm{OM}, \mathrm{g} / \mathrm{kg}$ & 912 & 913 & 922 \\
$\mathrm{CP}, \mathrm{g} / \mathrm{kg}$ & 77.4 & 66.6 & 65.2 \\
$\mathrm{NDIN}, \%$ of total N & 6.94 & 7.54 & 9.18 \\
apNDF, g/kg & 618 & 628 & 679 \\
iNDF, g/kg & 225 & 251 & 272
\end{tabular}

${ }^{a}$ pdDM - potentially digestible forage dry matter; OM - organic matter; CP - crude protein; NDIN - neutral detergent insoluble N; apNDF - neutral detergent fiber corrected for ash and protein residue; iNDF - indigestible neutral detergent fiber

${ }^{b}$ pdDM was estimated for forage sampled in the area delimited by a metal square $0.5 \mathrm{~m} \times 0.5 \mathrm{~m}$; chemical composition was evaluated in the handplucked forage sample
The potentially digestible dry matter (pdDM) was estimated using the second sample collected in each month, as described previously, using the following eq. [5]:

$$
\begin{aligned}
& \operatorname{pdDM}(\% ; \text { dry matter basis }) \\
& \quad=0.98 \times(100-\mathrm{NDF})+(\mathrm{NDF}-\mathrm{iNDF})
\end{aligned}
$$

where: 0.98 is the true digestibility coefficient of intracellular content; NDF is forage content of neutral detergent fiber; and iNDF is forage content of indigestible neutral detergent fiber.

In the breeding season, cows were synchronized using the following protocol: on $\mathrm{d} 0$, an intravaginal device of progesterone release (Tecnopec Primer ${ }^{\circ}$, São Paulo, Brazil) was inserted, and an i.m. injection of $2.0 \mathrm{mg}$ of estradiol benzoate (Tecnopec RIC-BE ${ }^{\oplus}$, São Paulo, Brazil) was performed. On day seven, the intravaginal device was removed and cows received a $2-\mathrm{mL}$ injection of cloprosterol sodium (MSD Saúde Animal Ciosin ${ }^{\bullet}$, São Paulo, Brazil). Finally, on day eight, cows received $0.5 \mathrm{~mL}$ of estradiol cypionate i.m. (Zoetis-Pfizer E.C.P. ${ }^{\circ}$, Campinas, Brazil). Fixed time artificial insemination (FTAI) was performed $46-52 \mathrm{~h}$ following intravaginal device removal (day nine). Semen from five Nellore sires were randomly assigned to each cow. The protocol was repeated once more in a way that cows that did not conceive were inseminated again $32 \mathrm{~d}$ after the first FTAI. Pregnancy diagnosis was determined via trans-rectal ultrasonography $30 \mathrm{~d}$ after each FTAI. The number of days from parturition to re-conception was calculated for each cow.

Response variables were analyzed using GLIMMIX in SAS 9.4. Initial BW of cows was used as a covariate for data analysis. Treatments were compared using orthogonal contrasts, contrasts were constructed in order to evaluate the effects of supplementation, and the linear and quadratic effects of days receiving supplementation (30, 60 and $90 \mathrm{~d}$ ). For the variables which didn't present supplementation effect but a linear or quadratic effect was significant, a Dunnett's test was performed to identify whether a supplemented treatment differed from the control. Significance was considered at $P<0.05$.

\section{Experiment 2 - Intake and metabolism}

In order to evaluate the effects of the amounts of supplement offered daily in Experiment 1 on intake and metabolism, a second experiment was conducted simultaneously. Four multiparous, five years old, single pregnant Nellore cows with $488 \pm 22 \mathrm{~kg}$ of BW, BCS of $4.7 \pm 0.3$, and $210 \pm 10 \mathrm{~d}$ of gestation were assigned to a $4 \times 4$ Latin square design, with experimental periods of $15 \mathrm{~d}$ each.

Cows were individually housed in an experimental area of Brachiaria decumbens divided into four paddocks of 
0.34 ha each, with free access to water, mineral salt and feeders. Experiment 2 started 15 d later than Experiment 1 .

The experimental treatments evaluated were: $3.0 \mathrm{~kg}-$ cows received $3.0 \mathrm{~kg}$ of supplement daily; $1.5 \mathrm{~kg}$ - cows received $1.5 \mathrm{~kg}$ of supplement daily; $1.0 \mathrm{~kg}$ - cows received $1.0 \mathrm{~kg}$ of supplement daily; and $0.0 \mathrm{~kg}$ - no concentrate supplement was fed. The supplement used was the same used in Experiment 1 (Table 1).

Pasture chemical composition (Table 3) was assessed by hand-plucked samples, collected on the eighth day of each experimental period. On the same day, a second pasture sample was also collected to estimate forage pdDM. Samples were collected and processed as described in Experiment 1.

After six days of adaptation to treatments in each period, a nine-day intake trial was carried out. To estimate fecal excretion, chromium oxide $\left(\mathrm{Cr}_{2} \mathrm{O}_{3}\right)$ was used as an external marker in the amount of $15 \mathrm{~g}$ per animal. The chromium oxide was packed in paper cartridges and delivered via the esophagus with a metal probe once daily, at 10:00. To estimate DM intake, iNDF was used as an internal marker. Once the intake trial had started, six days were allowed for stabilization of $\mathrm{Cr}_{2} \mathrm{O}_{3}$ excretion; and, after that, fecal samples were collected at $1500 \mathrm{~h}$ on the seventh day, at $1100 \mathrm{~h}$ on the eighth day, and at $0700 \mathrm{~h}$ on the ninth day of the intake trial $\left(13^{\text {th }}\right.$, $14^{\text {th }}$ and $15^{\text {th }} \mathrm{d}$ of each experimental period, respectively).

Feces samples were collected directly from the rectum of cows, at amounts of approximately $200 \mathrm{~g}$, dried $\left(60{ }^{\circ} \mathrm{C} / 72 \mathrm{~h}\right)$ and mill grinded as described for forage samples. Ground samples were proportionally combined to a pooled three-day sample per animal per period.

Samples of forage, feces and supplement were analyzed for DM, CP, ash, apNDF, and iNDF following procedures

Table 3 Potentially digestible forage mass and chemical composition of forage in Experiment 2

\begin{tabular}{lllll}
\hline Item $^{\text {a,b }}$ & \multicolumn{4}{l}{ Experimental period } \\
\cline { 2 - 5 } & 1 & 2 & 3 & 4 \\
\hline pdDM, kg/hm & 4320 & 3740 & 3245 & 1640 \\
OM, g/kg & 925 & 917 & 922 & 938 \\
CP, g/kg & 68.1 & 75.7 & 59.8 & 52.3 \\
NDIN, \% of total N & 10.4 & 10.4 & 12.3 & 10.9 \\
apNDF, g/kg & 652 & 644 & 712 & 719 \\
iNDF, g/kg & 257 & 239 & 312 & 345
\end{tabular}

${ }^{a}$ pdDM - potentially digestible forage dry matter; OM - organic matter; CP - crude protein; NDIN - neutral detergent insoluble N; apNDF - neutral detergent fiber corrected for ash and protein residue; iNDF - indigestible neutral detergent fiber

${ }^{b}$ pdDM was estimated for forage sampled in the area delimited by a metal square $0.5 \mathrm{~m} \times 0.5 \mathrm{~m}$; chemical composition was evaluated in the handplucked forage sample previously described for Experiment 1. Fecal samples were also analyzed for levels of chromium by atomic absorption spectrophotometry (index INCT-CA M-005/1) and titanium dioxide by colorimetry (index INCT-CA M-007/1), as recommended by Detmann et al. [8].

Fecal excretion (FE) was estimated by the ratio of chromium oxide and its concentration in the feces. Dry matter intake (DMI) was estimated by using iNDF as an internal marker and calculated by the following equation:

$$
\begin{aligned}
\text { DMI }(\mathrm{kg} / \mathrm{d})= & {[(\mathrm{FE} \times \mathrm{iNDF} \text { feces }-\mathrm{iNDF} \text { supplement })} \\
& \div \mathrm{iNDF} \text { forage }]+\mathrm{SI}
\end{aligned}
$$

where $\mathrm{FE}$ is the fecal excretion $(\mathrm{kg} / \mathrm{d})$; iNDF feces is the concentration of iNDF in the feces $(\mathrm{kg} / \mathrm{kg})$; iNDF supplement is the iNDF in the supplement $(\mathrm{kg} / \mathrm{d})$; iNDF forage is the concentration of iNDF in forage $(\mathrm{kg} / \mathrm{kg})$ and SI is DM supplement intake.

At the $15^{\text {th }} \mathrm{d}$ of each period, two blood samples were collected immediately before and $4 \mathrm{~h}$ after supplementation, to estimate insulin levels pre- and postsupplementation, respectively. Blood was collected in tubes with clot activator and gel for serum separation (BD Vacuntainer ${ }^{\circ}$ SST II Plus, São Paulo, Brazil), centrifuged at 3,600×g for $20 \mathrm{~min}$ and serum was immediately frozen at $-20{ }^{\circ} \mathrm{C}$ in duplicate until further analysis. The same blood collected $4 \mathrm{~h}$ after supplementation was used for quantification of serum urea concentrations.

Insulin was analyzed by the chemiluminescent method using Access Ultrasensitive Insulin Reagent (Ref. Number 33410, Beckman Coulter ${ }^{\circ}$, Brea, USA) in the Access 2 Immunoassay System (Beckman Coulter Inc., Brea, USA). Urea was quantified by an enzymatic-colorimetric method using reagents provided by commercial kits (Ref. Number K056, Bioclin ${ }^{\circ}$ Quibasa, Belo Horizonte, Brazil) in an automatic biochemistry analyzer (Mindray BS200E, Shenzhen, China). Serum urea N (SUN) was estimated as $46.67 \%$ of total blood urea.

Spot urine sampling at the $15^{\text {th }}$ day of each experimental period (collected immediately before the $4 \mathrm{~h}$ after supplementation blood sampling) was used to assess the excretion of urinary nitrogenous compounds [9]. Urine volume was estimated using creatinine concentration as a marker and assuming a daily creatinine excretion $(\mathrm{mg} / \mathrm{d})$ of $34.5 \times \mathrm{SBW}^{0.9491}$ [10]. Microbial N synthesis was estimated by using the technique of the purine derivatives in urine. Allantoin was estimated by colorimetry [11]. The urinary concentrations of creatinine and uric acid were obtained by colorimetric and enzymatic-colorimetric methods, respectively. The analyses of creatinine and uric acid were performed in an automatic biochemistry analyzer (Mindray BS200E, Shenzhen, China) using commercial kits (Ref. Number K067 for creatinine and K139 for uric acid, Bioclin ${ }^{\circ}$ Quibasa, Belo Horizonte, Brazil). 
Excretion of the purine derivatives in urine was calculated by the sum of the allantoin and uric acid excretions, which were obtained by the product between their concentrations in urine by the daily urinary volume. Absorbed purines were calculated from the excretion of purine derivatives [12], as follows:

$$
Y=\frac{x-0.301 \times B W^{0.75}}{0.8}
$$

where $\mathrm{Y}=$ absorbed purines $(\mathrm{mmol} / \mathrm{d}), x=$ excretion of purine derivatives $(\mathrm{mmol} / \mathrm{d}), 0.8=$ recovered absorbed purines. The $0.301 \times \mathrm{BW}^{0.75}$ value $=$ endogenous excretion of purine derivates.

Ruminal synthesis of nitrogen compounds was calculated as a function of the absorbed purines [12]:

$$
Z=\frac{70 \times Y}{0.93 \times 0.137 \times 1,000}
$$

where $\mathrm{Z}$ = ruminal synthesis of nitrogen compounds (g/ d), $\mathrm{Y}=$ absorbed purines $(\mathrm{mmol} / \mathrm{d}), 70=$ purine $\mathrm{N}$ content $(\mathrm{mg} / \mathrm{mol}), 0.93=$ purine digestibility and 0.137 = relation of purine $\mathrm{N}$ :total $\mathrm{N}$ of microorganisms.

Linear, quadratic and cubic effects of amount of supplement fed daily were analyzed using GLIMMIX in SAS 9.4. Animal and period were considered as random effects. Significance was assumed at $P<0.05$.

\section{Results}

\section{Experiment 1}

There was a linear effect of number of days of supplementation on cow BW at calving (Table 4; $P<0.05$ ). Body weight at calving ranged from $508 \mathrm{~kg}$ for cows in the 30-d strategy to $531 \mathrm{~kg}$ for cows in the 90-d strategy. Supplemented treatments did not differ from the control by Dunnett's test as well. Looking at the individual means of each treatment, can be observed that, actually, control cows had a BW at calving intermediate compared to the supplemented cows. It possibly reflects the small numbers of animals used in this study coupled with the variability of the variable in question. Birth BW of calves averaged $34.4 \mathrm{~kg}$ and was not different among supplementation strategies used for their mothers in the last third of gestation $(P>0.10)$.

Thirty-one days after calving, cows that received supplementation pre-calving tended to be heavier $(480 \mathrm{~kg}$, $P<0.10)$ compared to control cows $(465 \mathrm{~kg})$. Supplemented cows also lost less BW from parturition to $31 \mathrm{~d}$ post-calving $(P<0.05)$; within the supplemented treatments, there was a quadratic effect of the number of days of supplementation on post-partum BW change $(P<0.05)$ : cows from the 60-d strategy lost less BW $(-25 \mathrm{~kg})$ compared to cows in the $30-\mathrm{d}$ and $90-\mathrm{d}$ strategies $(-50 \mathrm{~kg}$ on average). Nevertheless, supplementation or level of supplementation did not affect BCS at any time $(P>0.10)$.

\begin{tabular}{|c|c|c|c|c|c|c|c|c|}
\hline \multirow[t]{2}{*}{ Item $^{a}$} & \multicolumn{4}{|c|}{ Treatment $^{b}$} & \multirow[t]{2}{*}{ SEM } & \multicolumn{3}{|c|}{$P$-value ${ }^{c}$} \\
\hline & $30-d$ & $60-d$ & 90-d & Control & & $S$ & L & Q \\
\hline Supplement fed, kg/d & 3.00 & 1.50 & 1.00 & - & & & & \\
\hline \multicolumn{9}{|l|}{ Cow BW, kg, cow BCS and calf BW, kg } \\
\hline Initial BW & 494 & 517 & 503 & 503 & 18.0 & 0.95 & 0.74 & 0.43 \\
\hline Initial BCS & 4.66 & 4.65 & 4.54 & 4.87 & 0.20 & 0.28 & 0.65 & 0.85 \\
\hline Calving BW & 508 & 515 & 531 & 522 & 6.79 & 0.56 & 0.02 & 0.55 \\
\hline Calving BCS & 4.74 & 4.83 & 4.83 & 4.82 & 0.15 & 0.95 & 0.70 & 0.82 \\
\hline Calf birth BW & 33.8 & 31.7 & 35.8 & 36.2 & 1.93 & 0.28 & 0.43 & 0.10 \\
\hline Cow BW 31 d after calving & 468 & 490 & 482 & 465 & 7.73 & 0.09 & 0.21 & 0.15 \\
\hline BW change from parturition to day 31 post-calving & -46.7 & -24.9 & -53.5 & -62.1 & 8.24 & 0.04 & 0.58 & 0.03 \\
\hline Breeding season BCS & 5.00 & 5.11 & 4.83 & 5.03 & 0.21 & 0.84 & 0.57 & 0.43 \\
\hline \multicolumn{9}{|l|}{ Progesterone concentration, ng/dL } \\
\hline $21 \mathrm{~d}$ after calving & $0.27^{*}$ & 0.21 & 0.12 & 0.14 & 0.06 & 0.34 & 0.05 & 0.82 \\
\hline $31 \mathrm{~d}$ after calving & 1.24 & 0.70 & 0.69 & 0.14 & 0.37 & 0.08 & 0.29 & 0.55 \\
\hline \multicolumn{9}{|l|}{ Cow reproductive performance, $\%$} \\
\hline Calving to conception, $d$ & 57.2 & 63.1 & $84.2^{*}$ & 64.1 & 5.85 & 0.53 & 0.01 & 0.30 \\
\hline
\end{tabular}

Table 4 Cow BW and BCS, calf BW, cow progesterone concentrations and reproductive performance

${ }^{\mathrm{a}} \mathrm{BW}$ - body weight; BCS - body condition score; FTAI - fixed time artificial insemination

${ }^{\mathrm{b}}$ Treatments: $30-\mathrm{d}$ - cows received $3.0 \mathrm{~kg}$ of concentrate supplement beginning $30 \mathrm{~d}$ prior to calving; 60 - $\mathrm{d}$ - cows received $1.5 \mathrm{~kg}$ of concentrate supplement beginning $60 \mathrm{~d}$ prior to calving; $90-\mathrm{d}$ - cows received $1.0 \mathrm{~kg}$ of concentrate supplement beginning $90 \mathrm{~d}$ prior to calving; and control - no concentrate supplement was fed

'S - effect of supplementation, supplemented treatments compared to the control; L and Q - effects of linear and quadratic order of supplement delivery strategy $(30,60$ or $90 \mathrm{~d}) .{ }^{*}$ Means statistically different from the control by Dunnett's test 
At $21 \mathrm{~d}$ post-calving, progesterone concentration linearly reduced with an increase in days of supplementation $(P=0.05)$, cows in the 30 -d strategy had higher progesterone concentration compared to control cows. Ten days later, at $31 \mathrm{~d}$ post-calving, supplemented cows tended to have greater progesterone concentration compared to cows receiving no supplement $(P<0.10)$.

A significant linear effect on interval from parturition to conception $(P<0.05)$ was observed, with the highest calving to conception interval being observed for cows in the 90-d strategy.

\section{Experiment 2}

Level of supplementation linearly increased DM intake $(\mathrm{kg} / \mathrm{d}$ and $\mathrm{g} / \mathrm{kg}$ of BW), DM digested $(\mathrm{kg} / \mathrm{d}$ and $\mathrm{g} / \mathrm{kg}$ of BW), OM $(\mathrm{kg} / \mathrm{d}$ and $\mathrm{g} / \mathrm{kg}$ of BW) and OM digested $(\mathrm{kg} /$ $\mathrm{d})$, and crude protein $(\mathrm{g} / \mathrm{d}-$ Table $5 ; P<0.05)$. There was also a cubic effect of the level of supplementation on intake of crude protein $(\mathrm{g} / \mathrm{d} ; P<0.05)$. There was no effect of the level of supplementation on intake $(\mathrm{g} / \mathrm{d}$ and $\mathrm{g} / \mathrm{kg} \mathrm{BW}$ ) of forage DM, forage OM, forage apNDF, apNDF and iNDF.

Level of supplementation increased the digestibility of $\mathrm{OM}$ and $\mathrm{CP}$ linearly $(P<0.05$; Table 6$)$. There was also a cubic effect of the level of supplementation on digestibility of $\mathrm{OM}(P<0.05)$.

The microbial $\mathrm{N}$ produced $(\mathrm{g} / \mathrm{d})$, the efficiency of microbial $\mathrm{N}$ produced in relation to $\mathrm{N}$ ingested and the efficiency of microbial $\mathrm{N}$ produced in relation to $\mathrm{OM}$ digested were not different among levels of supplementation $(P>0.10$; Table 7$)$. Level of SUN was also similar among treatments $(P>0.10)$, but ureic nitrogen excreted (g/d, UUN) tended to increase linearly with level of supplementation $(P<0.10)$.

Pre-supplementation levels of insulin were not different according to the level of supplementation $(P>0.10$; Table 8 ), but insulin levels $4 \mathrm{~h}$ after supplementation increased linearly with the amount of supplement fed $(P<0.05)$.

Table 5 Intake according to amount of supplement fed to cows in the last third of gestation

\begin{tabular}{|c|c|c|c|c|c|c|c|c|}
\hline \multirow[t]{2}{*}{ Item $^{a}$} & \multicolumn{4}{|c|}{ Treatment $^{\mathrm{b}}$} & \multirow[t]{2}{*}{ SEM } & \multicolumn{3}{|c|}{$P$-value ${ }^{c}$} \\
\hline & $3.0 \mathrm{~kg}$ & $1.5 \mathrm{~kg}$ & $1.0 \mathrm{~kg}$ & $0.0 \mathrm{~kg}$ & & L & Q & $C$ \\
\hline \multicolumn{9}{|c|}{ Intake per day, kg/d } \\
\hline Forage DM & 5.56 & 5.69 & 6.00 & 5.61 & 0.72 & 0.96 & 0.73 & 0.86 \\
\hline DM & 8.03 & 6.92 & 6.82 & 5.61 & 0.72 & 0.05 & 0.94 & 0.15 \\
\hline DM digested & 4.00 & 2.97 & 2.76 & 2.08 & 0.45 & 0.01 & 0.67 & 0.08 \\
\hline Forage OM & 5.11 & 5.26 & 5.55 & 5.22 & 0.65 & 0.90 & 0.72 & 0.89 \\
\hline $\mathrm{OM}$ & 7.51 & 6.46 & 6.35 & 5.22 & 0.65 & 0.05 & 0.95 & 0.15 \\
\hline OM digested & 4.03 & 3.01 & 2.83 & 2.13 & 0.41 & 0.01 & 0.68 & 0.06 \\
\hline Forage apNDF & 3.70 & 3.89 & 4.11 & 3.85 & 0.48 & 0.83 & 0.66 & 0.94 \\
\hline apNDF & 4.11 & 4.09 & 4.25 & 3.85 & 0.48 & 0.72 & 0.71 & 0.68 \\
\hline iNDF & 1.56 & 1.69 & 1.71 & 1.60 & 0.19 & 0.88 & 0.53 & 0.95 \\
\hline$C P, g / d$ & 882 & 613 & 556 & 359 & 58.8 & $<0.01$ & 0.48 & $<0.01$ \\
\hline \multicolumn{9}{|c|}{ Intake per kg BW, g/kg BW } \\
\hline Forage DM & 9.95 & 9.78 & 10.15 & 9.58 & 1.22 & 0.84 & 0.88 & 0.77 \\
\hline DM & 14.35 & 11.92 & 11.53 & 9.58 & 1.23 & 0.03 & 0.85 & 0.12 \\
\hline DM digested & 7.16 & 5.09 & 4.68 & 3.55 & 0.77 & 0.01 & 0.54 & 0.07 \\
\hline Forage OM & 9.14 & 9.05 & 9.39 & 8.92 & 1.12 & 0.89 & 0.87 & 0.81 \\
\hline $\mathrm{OM}$ & 13.42 & 11.13 & 10.74 & 8.92 & 1.13 & 0.03 & 0.84 & 0.12 \\
\hline OM digested & 5.06 & 4.74 & 4.75 & 6.25 & 0.95 & 0.24 & 0.20 & 0.39 \\
\hline Forage apNDF & 6.64 & 6.70 & 6.94 & 6.59 & 0.84 & 0.97 & 0.81 & 0.87 \\
\hline apNDF & 7.36 & 7.05 & 7.17 & 6.59 & 0.84 & 0.54 & 0.88 & 0.61 \\
\hline iNDF & 2.81 & 2.93 & 2.87 & 2.74 & 0.33 & 0.89 & 0.70 & 0.99 \\
\hline
\end{tabular}

${ }^{\mathrm{a} D M}$ - dry matter; OM - organic matter; apNDF - neutral detergent fiber corrected for ash and protein residue; iNDF - indigestible neutral detergent fiber; $\mathrm{CP}$ - crude protein

${ }^{\mathrm{b}}$ Treatments: $3.0 \mathrm{~kg}$ - cows received $3.0 \mathrm{~kg}$ of concentrate daily; $1.5 \mathrm{~kg}$ - cows received $1.5 \mathrm{~kg}$ of concentrate daily; $1.0 \mathrm{~kg}$ - cows received $1.0 \mathrm{~kg}$ of concentrate daily; and $0.0 \mathrm{~kg}$ - no concentrate supplement was fed

${ }^{c} \mathrm{~L}, \mathrm{Q}$ and $\mathrm{C}$ - effects of linear, quadratic and cubic order of level of supplementation 
Table 6 Coefficients of digestibility (\%) according to amount of supplement fed

\begin{tabular}{|c|c|c|c|c|c|c|c|c|}
\hline \multirow[t]{2}{*}{ Item $^{a}$} & \multicolumn{4}{|c|}{ Treatment $^{\mathrm{b}}$} & \multirow[t]{2}{*}{ SEM } & \multicolumn{3}{|c|}{$P$-value ${ }^{c}$} \\
\hline & $3.0 \mathrm{~kg}$ & $1.5 \mathrm{~kg}$ & $1.0 \mathrm{~kg}$ & $\overline{0.0 \mathrm{~kg}}$ & & $\mathrm{~L}$ & Q & C \\
\hline$\overline{\mathrm{OM}}$ & 53.87 & 45.94 & 44.44 & 39.57 & 3.30 & $<0.01$ & 0.42 & 0.01 \\
\hline NDD & 52.39 & 49.52 & 50.22 & 48.77 & 2.55 & 0.18 & 0.69 & 0.25 \\
\hline$C P$ & 48.12 & 39.14 & 36.54 & 17.70 & 8.98 & 0.03 & 0.53 & 0.11 \\
\hline
\end{tabular}

${ }^{\mathrm{D} D M}$ - dry matter; OM - organic matter; apNDF - neutral detergent fiber corrected for ash and protein residue; $\mathrm{CP}$ - crude protein

${ }^{\text {b}}$ Treatments: $3.0 \mathrm{~kg}$ - cows received $3.0 \mathrm{~kg}$ of concentrate daily; $1.5 \mathrm{~kg}$ - cows received $1.5 \mathrm{~kg}$ of concentrate daily; $1.0 \mathrm{~kg}$ - cows received $1.0 \mathrm{~kg}$ of concentrate daily; and $0.0 \mathrm{~kg}$ - no concentrate supplement was fed

${ }^{\mathrm{C}} \mathrm{L}, \mathrm{Q}$ and $\mathrm{C}$ - effects of linear, quadratic and cubic order of level of supplementation

\section{Discussion}

Nutritional status at calving is the most important factor that influences the interval from parturition to conception in beef cows. Postpartum nutrient intake can modulate the duration of the postpartum anestrous interval; however, if thin cows gain great amounts of weight after calving, ovulation occurs later than for cows that calve in good body condition and maintain body weight [2].

Cabral et al. [13] supplemented pregnant cows grazing pastures in similar conditions to the present study, but with different amounts of supplement per day, and observed a quadratic pattern in performance, with cows receiving $1.0 \mathrm{~kg}$ of supplement daily gaining more BW. The total amount of supplement provided for the $1.0 \mathrm{~kg}$ treatment in Cabral's work $(84 \mathrm{~kg})$ was similar to the present study $(90 \mathrm{~kg})$.

Based on the magnitude of post-partum BW change, supplementing cows with $1.5 \mathrm{~kg}$ of supplement during the last $60 \mathrm{~d}$ prior to calving was the most efficient strategy to lessen the post-partum negative energy balance, since cows on this strategy lost about half $(-25 \mathrm{~kg})$ of the BW lost in the $30-\mathrm{d}$ and $90-\mathrm{d}$ strategies $(-50 \mathrm{~kg})$. The differences found in BW changes are related to supplementing proper amounts of nutrients at key times and the effects when this supplement is removed from cow diet and its impact on cow metabolism, in addition to changes that naturally occur due to calving and lactation. Therefore, supplementing adequate amounts of nutrients at times of higher requirements (last $60 \mathrm{~d}$ of gestation) $[4,5]$ seems to metabolically prepare the cow for the post-calving period, not only due to accretion in body reserves, but also due to its effects on cow metabolism later on, when supplements are no longer provided. These results provide evidence that adopting a strategy to deliver the same amount of supplement $60 \mathrm{~d}$ prior to calving, instead of the usually recommended $90 \mathrm{~d}$, may not only be economical, but also improve cow post-partum performance.

Previous studies in cattle during late gestation [14] have provided evidence that feeding systems during the last third of gestation can alter the subsequent birth weight of the progeny, suggesting that the maternal dietary energy source may affect fetal growth [15]. Although the maternal intake of protein has also been shown to be an important factor for fetal growth, Summers et al. [16] found no difference in calf birth BW according to the supplementation strategy applied to their mothers. Similarly, no difference was observed for calf birth BW in the present study, probably because throughout the experiment forage presented median quality (Table 2).

In tropical pastures, the use of energetic-protein supplements can impact forage intake in different ways, depending largely on forage quality, amount and quality of supplement provided [17-19]. Linear increase of DM, $\mathrm{OM}$ and $\mathrm{CP}$ intake with levels of supplementation observed in the present work was simply due to the increase in supplement intake, as no difference in forage DM intake was observed in the present study.

During the intake and metabolism experiment (Table 3), average forage $\mathrm{CP}$ content was adequate or slightly below the minimum required by ruminal microorganisms [17]. In this way, the level of supplementation did not affect apNDF digestibility or intake.

Level of supplementation linearly increased insulin levels post-supplementation. For animals in an exclusive

Table 7 Nitrogen utilization according to amount of supplement fed

\begin{tabular}{|c|c|c|c|c|c|c|c|c|}
\hline \multirow[t]{2}{*}{ Item $^{a}$} & \multicolumn{4}{|c|}{ Treatment $^{\mathrm{b}}$} & \multirow[t]{2}{*}{ SEM } & \multicolumn{3}{|c|}{$P$-value ${ }^{c}$} \\
\hline & $3.0 \mathrm{~kg}$ & $1.5 \mathrm{~kg}$ & $1.0 \mathrm{~kg}$ & $0.0 \mathrm{~kg}$ & & $\bar{L}$ & Q & $C$ \\
\hline Nmic, g/d & 72.87 & 77.99 & 48.02 & 36.14 & 16.4 & 0.17 & 0.58 & 0.82 \\
\hline Nmic, g/g N ingested & 0.747 & 0.788 & 0.605 & 0.533 & 0.20 & 0.45 & 0.76 & 0.93 \\
\hline Nmic, g/kg OMD & 26.71 & 26.21 & 19.99 & 14.87 & 7.19 & 0.25 & 0.72 & 0.67 \\
\hline $\mathrm{SUN}, \mathrm{mg} / \mathrm{dL}$ & 13.77 & 12.72 & 12.37 & 10.85 & 1.70 & 0.20 & 0.88 & 0.41 \\
\hline UUN, g/d & 61.36 & 47.59 & 33.35 & 32.39 & 9.85 & 0.09 & 0.53 & 0.48 \\
\hline
\end{tabular}

${ }^{\mathrm{a}} \mathrm{Nmic}$ - microbial N; OMD - organic matter digested; SUN - Serum urea nitrogen; UUN - Urine urea N

${ }^{\mathrm{b}}$ Treatments: $3.0 \mathrm{~kg}$ - cows received $3.0 \mathrm{~kg}$ of concentrate daily; $1.5 \mathrm{~kg}$ - cows received $1.5 \mathrm{~kg}$ of concentrate daily; $1.0 \mathrm{~kg}$ - cows received $1.0 \mathrm{~kg}$ of concentrate daily; and $0.0 \mathrm{~kg}$ - no concentrate supplement was fed

${ }^{\mathrm{C}} \mathrm{L}, \mathrm{Q}$ and $\mathrm{C}$ - effects of linear, quadratic and cubic order of level of supplementation 
Table 8 Insulin levels ( $\mu \mathrm{lU} / \mathrm{mL}$ ) according to amount of supplement fed

\begin{tabular}{|c|c|c|c|c|c|c|c|c|}
\hline \multirow[t]{2}{*}{ Item } & \multicolumn{4}{|c|}{ Treatment $^{a}$} & \multirow[t]{2}{*}{ SEM } & \multicolumn{3}{|c|}{$P$-value ${ }^{b}$} \\
\hline & $3.0 \mathrm{~kg}$ & $1.5 \mathrm{~kg}$ & $1.0 \mathrm{~kg}$ & $0.0 \mathrm{~kg}$ & & L & Q & $C$ \\
\hline Pre-supplementation & 1.68 & 1.50 & 1.18 & 1.13 & 0.43 & 0.13 & 0.79 & 0.63 \\
\hline Post-supplementation & 2.20 & 1.48 & 1.33 & 1.25 & 0.38 & 0.03 & 0.21 & 0.13 \\
\hline
\end{tabular}

${ }^{a}$ Treatments: $3.0 \mathrm{~kg}$ - cows received $3.0 \mathrm{~kg}$ of concentrate daily; $1.5 \mathrm{~kg}$ - cows received $1.5 \mathrm{~kg}$ of concentrate daily; $1.0 \mathrm{~kg}$ - cows received $1.0 \mathrm{~kg}$ of concentrate daily; and $0.0 \mathrm{~kg}$ - no concentrate supplement was fed

${ }^{b} \mathrm{~L}, \mathrm{Q}$ and $\mathrm{C}$ - effects of linear, quadratic and cubic order of level of supplementation

forage diet, the relative amount of propionate, a glycogenic precursor, available for metabolism is low, and supplementation significantly increases the proportion of propionate produced in the rumen [20].

Hawkins et al. [21] have suggested that an increase in insulin, concomitant with a decrease in growth hormone $(\mathrm{GH})$, is an important relationship to consider for evaluating the impact of nutrition on reproduction. Insulin is an important mediator of nutritional effects on follicular dynamics in cattle, and can stimulate the release of gonadotropin-releasing hormone $(\mathrm{GnRH})$ from the hypothalamus. In the ovaries, insulin may also stimulate cell proliferation and steroidogenesis [22]. In accordance with these findings, in the present study, supplementing with higher amounts of supplement daily linearly increased progesterone concentrations after calving.

The interval from calving to conception greatly influences the profitability of beef production. Hence, in beef systems, it is recommended that the calving interval is no longer than $85 \mathrm{~d}$ in order to assure the cow will produce a calf per year. Cows that conceive early calve early, and have a better opportunity to start reproductive cycles in time to re-conceive in the next breeding season. The calving date also affects the value of offspring, demonstrating the importance of supplementation strategies to improve early re-conception.

Cushman et al. [23] and Funston et al. [24] reported that heifer calves born early tend to conceive early in their first breeding season and remain in the herd. The calving date can also impact male offspring performance; steer calves born earlier in the calving season have greater weaning $\mathrm{BW}$, hot carcass weight and marbling scores [24]. In this way, increasing early calving by early conception may increase progeny value at weaning, enhance carcass value of the steers and increase heifer pregnancy rates in their first breeding season.

All treatments in the present study presented acceptable calving intervals, but cows receiving higher amounts of supplement per day for a reduced number of days had lower calving intervals (30-d and 60-d vs. 90-d).

\section{Conclusions}

Providing $1.5 \mathrm{~kg}$ of supplement during the last $60 \mathrm{~d}$ of gestation, instead of $90 \mathrm{~d}$ that are usually recommended, is a nutritional management strategy that can be adopted to improve cow performance, reducing the magnitude of BW lost after calving and reducing the number of days from calving to re-conception in the following breeding season, with no negative effect on forage intake or digestibility.

\section{Abbreviations}

apNDF: Neutral detergent fiber corrected for ash and protein residue; BCS: Body condition score; BW: Body weight; CP: Crude protein; DM: Dry matter; FTAl: Fixed time artificial insemination; iNDF: Indigestible neutral detergent fiber; NDF: Neutral detergent fiber; OM: Organic matter; pdDM: potentially digestible dry matter; SUN: Serum urea N; UUN: Urine urea N

\section{Acknowledgements}

The authors thank to Fapemig and CNPq for financial support and CNPq and Capes for the scholarships provided to the first author.

\section{Funding}

This research was supported by funding from Fapemig - Fundação de Amparo à Pesquisa de MG, CNPq - Conselho Nacional de Desenvolvimento Científico e Tecnológico and Capes - Coordenação de Aperfeiçoamento de Pessoal de Nível Superior.

\section{Availability of data and materials}

The data generated during the current study are available from the corresponding author on reasonable request.

\section{Authors' contributions}

AGS, conceived the study, carried out the experimental trial, performed the statistical analysis and wrote the manuscript. MFP, contributed to draft the manuscript, and coordinate the research group. ED and HJF, contributed to the statistical analysis and to draft the manuscript. LSA, REMO, contributed to designing the experiment and to draft the manuscript. WC, JACL, FHM, $M B M, J A B$, carried out the experimental trial, performed the chemical analysis and contributed to draft the manuscript. All authors read and approved the final manuscript.

\section{Ethics approval and consent to participate}

This manuscript does not involve any human subject, or human data.

\section{Consent for publication}

This manuscript does not contain any individual personal data.

\section{Competing interests}

The authors declare that they have no competing interests.

\section{Author details}

${ }^{1}$ Universidade Federal de Viçosa, Viçosa, Minas Gerais 36570-000, Brazil. ${ }^{2}$ Present Address: Universidade Federal de Mato Grosso do Sul, Campo Grande, Mato Grosso do Sul 79074-460, Brazil. ${ }^{3}$ Universidade Estadual de Mato Grosso do Sul, Aquidauana, Mato Grosso do Sul 79200-000, Brazil. ${ }^{4}$ Biotran - Biotecnologia e Treinamento em Reprodução Animal, Alfenas, Minas Gerais 37130-000, Brazil. ' Universidade Federal do Acre, Rio Branco, Acre 69920-900, Brazil. 
Received: 23 November 2016 Accepted: 31 August 2017

Published online: 01 October 2017

\section{References}

1. Madureira ED, Maturana Filho M, Lemes KM, Silva JCB, Santini T. Análise crítica de fatores que interferem na fertilidade de vacas zebuínas. In: Proc of 9th symposium of beef cattle production. Viçosa, Brazil: Universidade Federal de Viçosa; 2014. p. 367-400.

2. Wettemann RP, Lents CA, Ciccioli NH, White FJ, Rubio I. Nutritional- and pre-weaning-mediated anovulation in beef cows. J Anim Sci. 2002;81(Suppl 2):E48-59.

3. Detmann E, Gionbelli MP, Paulino MF, Valadares Filho SC, Rennó LN. Considerations on research methods applied to ruminants under grazing. Nutritime. 2016;13:4711-31.

4. Valadares Filho SC, Costa e-Silva LF, Gionbelli MP, Rotta PP, Marcondes MI, Chizzotti ML. BR-CORTE 3.0 - Nutrient requirements of zebu and crossbred cattle. 3rd Ed. Viçosa: Universidade Federal de Viçosa; 2016.

5. National Research Council - NRC. Nutrient requirements of beef cattle 8th ed. Washington: Academic Press; 2016

6. Gionbelli MP, Duarte MS, Valadares Filho SC, Detmann E, Chizzotti ML, Rodrigues FC, et al. Achieving body weight adjustments for feeding status and pregnant or non-pregnant condition in beef cows. PLoS One. 2015;10:e0112111.

7. Valente TNP, Detmann E, Queiroz AC, Valadares Filho SC, Gomes DI, Figueiras JF. Evaluation of ruminal degradation profiles of forages using bags made from different textiles. Rev Bras Zootec. 2011;40:2565-73.

8. Detmann E, Souza MA, Valadares Filho SC, Queiroz AC, Berchielli TT, Saliba EOS, et al. Métodos para análise de alimentos - INCT - Ciência Animal. Visconde do Rio Branco. Brazil: Suprema; 2012. 214p.

9. Valadares RFD, Broderick GA, Valadares Filho SC, Clayton MK. Effect of replacing alfafa silage with high moisture corn on ruminal protein synthesis estimated from excretion of total purine derivatives. J Dairy Sci. 1999:82:2686-96.

10. Silva LFC, Valadares Filho SC, Chizzotti ML, Rotta PP, Prados LF, Valadares RFD, et al. Creatinine excretion and relationship with body weight of Nellore cattle. Rev Bras Zootec. 2012;41:807-10.

11. Chen XB, Gomes MJ. Estimation of microbial protein supply to sheep and cattle basid on urinary excretion of purine derivatives-an overview of the technical details. Ocasional publication. Ed. Rowett Research Institute: Buchsburnd Aberdeen, UK; 1992. 21p.

12. Barbosa AM, Valadares RFD, Valadares Filho SC, Pina DS, Detmann E, Leão MI. Endogenous fraction and urinary recovery of purine derivatives obtained by different methods in Nellore cattle. J Anim Sci. 2011;89:510-9.

13. Cabral CHA, Paulino MF, de Paula NF, Valadares RFD, de Araújo FL. Levels of supplementation for grazing pregnant beef cows during the dry season. Rev Bras Zootec. 2012;41:2441-9.

14. Radunz AE, Fluharty FL, Day ML, Zerby HN, Loerch SC. Prepartum dietary energy source fed to beef cows: I. Effects on pre- and postpartum cow performance. J Anim Sci. 2010;88:2717-28.

15. Radunz AE, Fluharty FL, Zerby HN, Loerch SC. Winter-feeding systems for gestating sheep I. Effects on pre- and postpartum ewe performance and lamb progeny preweaning performance. J Anim Sci. 2011;89:467-77.

16. Summers AF, Meyer TL, Funston RN. Impact of supplemental protein source offered to primiparous heifers during gestation on I. Average daily gain, feed intake, calf birth body weight, and rebreeding in pregnant beef heifers. J Anim Sci. 2015;93:1865-70.

17. Lazzarini I, Detmann E, Sampaio CB, Paulino MF, Valadares Filho SC, de Souza MA, et al. Intake and digestibility in cattle fed low-quality tropical forage and supplemented with nitrogenous compounds. Rev Bras Zootec. 2009;38:2021-30

18. Costa VAC, Detmann E, Valadares Filho SC, Paulino MF, Henriques LT, Mantovni HC. Degradação in vitro da fibra em detergente neutro de forragem tropical de baixa qualidade em função de suplementação com proteína e/ou carboidratos. Rev Bras Zootec. 2008;37:494-503.

19. Costa VAC, Detmann E, Paulino MF, Valadares Filho SC, Carvalho IPC, Monteiro LP. Consumo e digestibilidade em bovinos em pastejo durante o período das águas sob suplementação com fontes de compostos nitrogenados e de carboidratos. Rev Bras Zootec. 2011;40:1788-98.

20. Huntington GB, Harmon DL, Richards CJ. Sites, rates, and limits of starch digestion and glucose metabolism in growing cattle. J Anim Sci. 2006;84(Suppl 1):E14-24.
21. Hawkins DE, Petersen MK, Thomas MG, Sawyer JE, Waterman RC. Can beef heifers and young postpartum cows be physiologically and nutritionally manipulated to optimize reproductive efficiency? J Anim Sci. 2000;77(Suppl 1):1-10.

22. Wettemann RP, Bossis I. Energy intake regulates ovarian function in beef cattle. J Anim Sci. 2000;77(Suppl 1):E1-E10.

23. Cushman RA, Kill LK, Funston RN, Mousel EM, Perry GA. Heifer calving date positively influences calf weaning weights through six parturitions. J Anim Sci. 2013;91:4486-91.

24. Funston RN, Musgrave JA, Meyer TL, Larson DM. Effect of calving distribution on beef cattle progeny performance. J Anim Sci. 2012;90:5118-21.

\section{Submit your next manuscript to BioMed Central and we will help you at every step:}

- We accept pre-submission inquiries

- Our selector tool helps you to find the most relevant journal

- We provide round the clock customer support

- Convenient online submission

- Thorough peer review

- Inclusion in PubMed and all major indexing services

- Maximum visibility for your research

Submit your manuscript at www.biomedcentral.com/submit
Biomed Central 